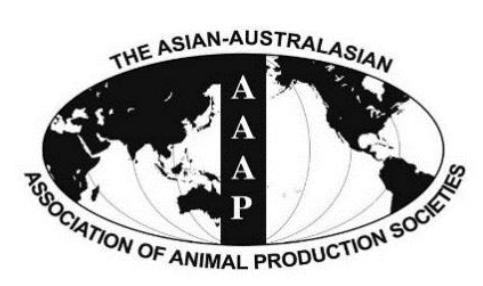

\title{
Effects of Palm Kernel Expellers on Productive Performance, Nutrient Digestibility, and White Blood Cells of Lactating Sows
}

\author{
J. Kim ${ }^{\text {a }}$ J. Seo ${ }^{1, a}$, W. Kim ${ }^{2, a}$, H. M. Yun ${ }^{3}$, S. C. Kim³ , Y. Jang, K. Jang, K. Kim, B. Kim, \\ S. Park, I. Park, M. K. Kim, K. S. Seo ${ }^{4}$, H. B. Kim ${ }^{3}$, I. H. Kim ${ }^{3}$, S. Seo ${ }^{2}$, and M. Song* \\ Department of Animal Science and Biotechnology, Chungnam National University, Daejeon 305-764, Korea
}

\begin{abstract}
This experiment was conducted to investigate the effects of palm kernel expellers on productive performance, nutrient digestibility, and changes in white blood cells (WBC) of lactating sows. A total of 14 sows $(200 \pm 12 \mathrm{~kg}$ of average body weight [BW]; 2.5 of average parity) were used and moved from gestation room to farrowing room on $\mathrm{d} 109$ of gestation. Sows were randomly assigned to 2 dietary treatments in a completely randomized design. The treatments were a diet based on corn and soybean meal (CON) and CON added with $20 \%$ of palm kernel expellers (PKE). Sows were fed the treatments for 28 days (weaning) after farrowing. Blood was collected from each sow and 4 randomly selected piglets from each sow before farrowing or on d 3, 7, or 14 of lactation. Sows were fed respective treatments containing $0.2 \%$ chromic oxide from d 15 to 21 of lactation. Fecal samples were collected daily for the last 3 days after the 4-d adjustment period. Measurements were performances and WBC changes of sows and litter, nutrient digestibility of sows, and daily diarrhea of litter. Sows fed PKE had greater average daily feed intake (7.38 vs $7.10 \mathrm{~kg} / \mathrm{d} ; \mathrm{p}<0.05)$ and lost less BW ($6.85 \mathrm{vs}-8.54 \mathrm{~kg} ; \mathrm{p}<0.05)$ and backfat depth $(-0.42 \mathrm{vs}-0.71 \mathrm{~mm} ; \mathrm{p}<0.05)$ than those fed CON. However, there were no differences on digestibility of dry matter, nitrogen, and energy and weaning to estrus interval of sows fed either CON or PKE. Piglets from sows fed PKE gained more BW (203 vs $181 \mathrm{~g} / \mathrm{d} ; \mathrm{p}=0.08)$ and had less frequency of diarrhea (6.80 vs $8.56 \% ; \mathrm{p}=0.07)$ than those from sows fed CON. On the other hand, no difference was found on preweaning mortality of piglets from sows fed either CON or PKE. Sows fed PKE had lower number of WBC $\left(9.57\right.$ vs $\left.11.82 \times 10^{3} / \mu \mathrm{L} ; \mathrm{p}=0.09\right)$ before farrowing than those fed CON, but no difference on $\mathrm{d} 3$ and 7 . Similarly, piglets from sows fed PKE had also lower number of WBC $\left(7.86\right.$ vs $\left.9.80 \times 10^{3} / \mu \mathrm{L} ; \mathrm{p}<0.05\right)$ on d 14 of lactation than those from sows fed CON, but no difference on $\mathrm{d} 3$ and 7 . In conclusion, addition of $20 \%$ palm kernel expellers to lactation diet based on corn and soybean meal had no negative effects on productive performance, nutrient digestibility, and WBC changes of lactating sows. (Key Words: Diarrhea, Lactating Sows, Nutrient Digestibility, Palm Kernel Expellers, Performance, White Blood Cells)
\end{abstract}

\section{INTRODUCTION}

Recently, the cost of traditional ingredients such as corn

\footnotetext{
* Corresponding Author: M. Song. Tel: +82-42-821-5776, Fax: $+82-$ 42-825-9754, E-mail: mhsong@ @ cnu.ac.kr

${ }^{1}$ Department of Animal Science, Pusan National University, Miryang $627-706$, Korea.

${ }^{2}$ Department of Animal Biosystem Sciences, Chungnam National University, Daejeon 305-764, Korea.

${ }^{3}$ Department of Animal Resource and Science, Dankook University, Cheonan 330-774, Korea.

${ }^{4}$ Department of Animal Science and Technology, Sunchon National University, Suncheon 540-742, Korea.

${ }^{a} \mathrm{Kim}, \mathrm{Seo}$, and Kim contributed equally to this work as the first authors.

Submitted Nov. 28, 2014; Revised Feb. 3, 2015; Accepted Mar. 14, 2015
}

and soybean meal has markedly increased due to increased biofuel production (Hoffman and Baker, 2011). This change has gradually increased use of cheaper co-products to partially replace corn and/or soybean meal emphasizing their importance in swine diets (Wachenheim et al., 2006).

Several co-product candidates are oilseed meals such as palm kernel meal, palm kernel expellers, copra meal, or so on. Among those candidates, the palm kernel expellers are a co-product from the kernels of oil palm fruits in tropical countries and are produced after the oils of fruits are removed by mechanical pressing extraction (Sulabo et al., 2013). Palm kernel co-products such as palm kernel expellers and meal have been primarily used in ruminant (Singhania et al., 2008) and poultry diets (Ravindran and Blair, 1992), not in swine diets because they contain high

Copyright $@ 2015$ by Asian-Australasian Journal of Animal Sciences This is an open-access article distributed under the terms of the Creative Commons Attribution Non-Commercial License (http://creativecommons.org/licenses/by-nc/3.0/) which permits unrestricted non-commercial use, distribution, and reproduction in any medium, provided the original work is properly cited. 
fiber content, low energy density, and poor amino acids (AA) composition compared with corn and soybean meal (NRC, 2012).

The nutritional value of palm kernel co-products in swine diets have been evaluated in diets for growing (Son et al., 2012, 2013, 2014; Sulabo et al., 2013) or finishing pigs (Kim et al., 2001; Ao et al., 2011), but there is limited information on the nutritional value of palm kernel coproducts in sow diets. Therefore, the objective of this experiment was to investigate the effects of addition of $20 \%$ palm kernel expellers in a typical lactation diet based on corn and soybean meal on productive performance, nutrient digestibility, and changes in white blood cells (WBC) of lactating sows.

\section{MATERIALS AND METHODS}

The experimental protocol for this study was reviewed and approved by the Animal Care and Use Committee of Dankook University.

\section{Experimental design, animals, and diets}

A total of 14 lactating sows (LandracexYorkshire; $200 \pm 12 \mathrm{~kg}$ of average body weight [BW]; 2.5 of average parity) were used in this experiment. On d 109 of gestation, sows were moved from gestation crates to farrowing crates equipped with a feeder and waterer in an environmentally controlled farrowing room and randomly assigned to dietary treatments. The dietary treatments were a typical lactation diet based on corn and soybean meal (CON) and CON added with $20 \%$ of palm kernel expellers (PKE). The dietary treatments were formulated to meet or exceed the NRC (2012) estimates of nutrient requirements of lactating sows. Palm kernel expellers was added to the diet to replace corn and soybean meal. More fat was also added to the PKE diet to make sure the two diets were formulated with similar metabolizable energy, crude protein, and AA levels (Table 1). Sows were fed $2.5 \mathrm{~kg}$ of the dietary treatments from $\mathrm{d}$ 109 of gestation until farrowing and allowed free access to the dietary treatments from farrowing until weaning. Diets and water were freely accessible at all times.

\section{Data and sample collection}

The amount of dietary treatments provided per sow was recorded from farrowing until weaning and feed refusals were weighed and recorded at weaning. Piglets were weaned at $26.7 \pm 1.3 \mathrm{~d}$ of age. Sow $\mathrm{BW}$ and ultrasonic backfat depth at the $\mathrm{P} 2$ position $(6.0$ to $6.5 \mathrm{~cm}$ from the dosal midline at the same level as the last rib curve) using a real-time ultrasound instrument (Piglot 105, SFK Technology, Herlev, Denmark) as well as litter weight were measured within $24 \mathrm{~h}$ after farrowing and at weaning. Other productive performances were also measured: weaning to
Table 1. Composition of experimental diets during lactation (asfed basis)

\begin{tabular}{|c|c|c|}
\hline \multirow{2}{*}{ Items } & \multicolumn{2}{|c|}{ Treatments } \\
\hline & $\mathrm{CON}$ & PKE \\
\hline \multicolumn{3}{|l|}{ Ingredient (\%) } \\
\hline Corn & 70.35 & 50.91 \\
\hline Soybean meal, $48 \%$ & 27.00 & 24.55 \\
\hline Palm kernel expellers & - & 20.00 \\
\hline Choice white grease & - & 2.00 \\
\hline Dicalcium phosphate & 1.40 & 1.15 \\
\hline Limestone & 0.85 & 0.90 \\
\hline Vitamin $_{\text {premix }}{ }^{1}$ & 0.20 & 0.20 \\
\hline Mineral premix ${ }^{2}$ & 0.20 & 0.20 \\
\hline L-lysine- $\mathrm{HCl}$ & - & 0.06 \\
\hline L-threonine & - & 0.03 \\
\hline Total & 100 & 100 \\
\hline \multicolumn{3}{|c|}{ Analyzed energy and nutrient contents } \\
\hline GE (Mcal/kg) & 3.79 & 3.82 \\
\hline $\mathrm{DM}(\%)$ & 89.23 & 89.62 \\
\hline $\mathrm{CP}(\%)$ & 19.33 & 18.54 \\
\hline Ether extract $(\%)$ & 3.15 & 5.39 \\
\hline Crude fiber $(\%)$ & 3.00 & 5.56 \\
\hline $\operatorname{Ash}(\%)$ & 5.14 & 5.27 \\
\hline $\operatorname{NDF}(\%)$ & 20.74 & 32.43 \\
\hline $\operatorname{ADF}(\%)$ & 4.23 & 11.47 \\
\hline \multicolumn{3}{|c|}{ Calculated nutrient contents } \\
\hline $\mathrm{ME}(\mathrm{Mcal} / \mathrm{kg})$ & 3.28 & 3.32 \\
\hline Calcium $(\%)$ & 0.76 & 0.76 \\
\hline Phosphorus (\%) & 0.64 & 0.63 \\
\hline Lysine $(\%)$ & 0.98 & 0.98 \\
\hline Methionine (\%) & 0.30 & 0.30 \\
\hline Threonine (\%) & 0.70 & 0.70 \\
\hline Tryptophan (\%) & 0.22 & 0.22 \\
\hline
\end{tabular}

$\mathrm{CON}$, control diet based on corn and soybean meal; PKE, $\mathrm{CON}+20 \%$ palm kernel expellers; GE, gross energy; DM, dry matter; $\mathrm{CP}$, crude protein; NDF, neutral detergent fiber; ADF, acid detergent fiber; ME, metabolizable energy.

${ }^{1}$ Provided per kilogram of diet: vitamin A, 10,000 IU; vitamin $\mathrm{D}_{3}, 2,000$ IU; vitamin E, $48 \mathrm{IU}$; vitamin $\mathrm{K}_{3}, 1.5 \mathrm{mg}$; riboflavin, $6 \mathrm{mg}$; niacin, 40 $\mathrm{mg}$; -pantothenic acid, $17 \mathrm{mg}$; biotin, $0.2 \mathrm{mg}$; folic acid, $2 \mathrm{mg}$; choline, $166 \mathrm{mg}$; vitamin $\mathrm{B}_{6}, 2 \mathrm{mg}$; and vitamin $\mathrm{B}_{12}, 28 \mu \mathrm{g}$.

${ }^{2}$ Provided per kilogram of diet: $\mathrm{Fe}, 90 \mathrm{mg}$ from iron sulfate; $\mathrm{Cu}, 15 \mathrm{mg}$ from copper sulfate; $\mathrm{Zn}, 50 \mathrm{mg}$ from zinc oxide; Mn, $54 \mathrm{mg}$ from manganese oxide; I, $0.99 \mathrm{mg}$ from potassium iodide; Se, $0.25 \mathrm{mg}$ from sodium selenite.

estrus interval and litter size (number of born alive and dead piglets). Presence of diarrhea from each pig was checked visually each day and recorded with two scales: presence of diarrhea or not. Frequency of diarrhea was calculated by counting pig days with presence of diarrhea.

Sows were fed respective dietary treatments containing $0.2 \%$ chromic oxide as an indigestible marker from d 15 to 21 of lactation. Fecal samples were collected twice daily by rectal palpation for the last 3 days after the 4-d adjustment 
period. The collected samples were pooled and stored at $-20^{\circ} \mathrm{C}$ until analysis. Diet samples were also collected from each batch of manufactured feed and stored at $-20^{\circ} \mathrm{C}$ until analysis. Whole blood samples were collected from a jugular vein of each sow using ethylenediaminetetraacetic acid (EDTA) tubes (Becton Dickinson Vacutainer Systems, Franklin Lakes, NJ, USA) with anticoagulant before farrowing and on d 3 and 7 of lactation. Four randomly selected piglets ( 2 barrows and 2 gilts) from each sow were also bled via venipuncture of a jugular vein using EDTA tubes with anticoagulant on d 3, 7, and 14 of lactation.

\section{Sample analyses}

Fecal samples were dried in a forced-air drying oven at $60^{\circ} \mathrm{C}$ and ground through a cyclone mill (Foss Tecator Sycltec 1093, Hillerød, Denmark) before analysis. Diet and fecal samples were analyzed for dry matter (method 930.15; AOAC International, 2005), gross energy using a bomb calorimeter (Parr 1281 Bomb Calorimeter, Parr Instrument Co., Moline, IL, USA), crude protein (method 990.03; AOAC International, 2005), ether extract (method 920.39; AOAC International, 2005), crude fiber (method 978.10; AOAC International, 2005), ash (method 942.05; AOAC International, 2005), neutral detergent fiber (Goering and van Soest, 1970), acid detergent fiber (method 973.18; AOAC International, 2005), and chromium content using an absorption spectrophotometer (Hitachi Z-5000 Absorption Spectrophotometer, Hitachi High-Technologies Co., Tokyo, Japan) based on the report by Williams et al. (1962). Apparent total tract digestibility of dry matter, nitrogen, and energy was calculated based on the index method (Adeola, 2001). Whole blood samples were analyzed for total WBC counts using a multiparameter, automated hematology analyzer calibrated for porcine blood (scil Vet abc hematology analyzer, scil animal care company, F-67120 Altorf, France).

\section{Statistical analyses}

Data were analyzed using the PROC general linear model procedure of SAS (SAS Inst. Inc., Cary, NC, USA) in a completely randomized design. The experimental unit was the sow or litter. The statistical model for sow and litter performance, nutrient digestibility of sow, and WBC counts of sow and piglets included effects of dietary treatment and parity as a covariate. The $x^{2}$ test was used for the frequency of diarrhea. Results are given as means \pm standard error of the mean. Statistical significance and tendency were considered at $\mathrm{p}<0.05$ and $0.05 \leq \mathrm{p}<0.10$, respectively.

\section{RESULTS AND DISCUSSION}

Feeding PKE to lactating sows increased $(\mathrm{p}<0.05)$ average daily feed intake $(\mathrm{ADFI})$ and reduced $(\mathrm{p}<0.05) \mathrm{BW}$
Table 2. Productive performance of lactating sows fed dietary treatments $^{1}$

\begin{tabular}{lcccc}
\hline \multirow{2}{*}{ Items } & \multicolumn{2}{c}{ Treatments } & \multirow{2}{*}{ SEM } & p-value \\
\cline { 2 - 3 } & CON & PKE & & \\
\hline Parity & 2.57 & 2.42 & 0.20 & 0.63 \\
Weaning days (d) & 27.29 & 26.14 & 0.44 & 0.09 \\
Feed intake (kg) & 193.68 & 190.62 & 2.79 & 0.44 \\
ADFI (kg/d) & 7.10 & 7.38 & 0.06 & $<0.05$ \\
Initial BW (kg) & 197.63 & 202.90 & 4.84 & 0.46 \\
Final BW (kg) & 189.09 & 194.88 & 5.35 & 0.44 \\
BW change (kg) & -8.54 & -6.85 & 0.51 & $<0.05$ \\
Initial backfat depth (mm) & 17.86 & 17.50 & 0.57 & 0.67 \\
Final backfat depth (mm) & 17.14 & 17.17 & 0.60 & 0.98 \\
Backfat depth change (mm) & -0.71 & -0.42 & 0.09 & $<0.05$ \\
Weaning to estrus interval & 7 & 7 & - & - \\
(<d 5, n) & & & & \\
Born alive piglets (n) & 12.86 & 12.57 & 1.06 & 0.85 \\
Died piglets (n) & 1.29 & 1.29 & 0.47 & 1.00 \\
Preweaning mortality $(\%)$ & 9.30 & 10.14 & 3.04 & 0.85 \\
Weaned piglets (n) & 11.57 & 11.29 & 0.91 & 0.83 \\
BW of born piglets (kg) & 1.44 & 1.45 & 0.08 & 0.94 \\
BW of weaned piglets (kg) & 6.38 & 6.68 & 0.24 & 0.37 \\
Average BW gain of piglets & 181 & 203 & 7.62 & 0.08
\end{tabular}

$(\mathrm{g} / \mathrm{d})$

CON, control diet based on corn and soybean meal; PKE, CON+20\% palm kernel expellers; SEM, standard error of the mean; ADFI, average daily feed intake; BW, body weight.

${ }^{1}$ Values are presented as the least squares mean of 7 replicates.

and backfat depth compared with CON (Table 2). However, there were no differences on weaning to estrus interval and number of weaned piglets of sows fed either CON or PKE. One of the most important points in the management program of lactating sows is the fast recovery of their feed intake because decreased feed intake after farrowing can negatively affect their milk production and maintenance as well as productive performance (Koketsu et al., 1996; Eissen et al., 2000). In addition, lactating sows generally use more energy for milk production and maintenance rather than growth, resulting in loss of their BW or backfat depth or other negative productive performances (Song et al., 2010). In the present experiment, however, the PKE did not negatively affect ADFI and BW and backfat depth changes of sows compared with CON.

There were no differences on apparent total tract digestibility of dry matter, nitrogen, and energy when lactating sows were fed either CON or PKE (Table 3). Lactating sows fed PKE may be expected to have poor performance and nutrient utilization compared with those fed CON because palm kernel expellers contains greater fiber content than corn or soybean meal (NRC, 2012; Sulabo et al., 2013). In addition, the digestibility of nutrients and energy is likely decreased as the concentration of fiber content in swine diets is increased (Noblet and 
Table 3. Effects of palm kernel expellers on apparent total tract digestibility, number of white blood cells, and frequency of diarrhea $^{1}$

\begin{tabular}{|c|c|c|c|c|}
\hline \multirow{2}{*}{ Items } & \multicolumn{2}{|c|}{ Treatments } & \multirow{2}{*}{ SEM } & \multirow{2}{*}{ p-value } \\
\hline & $\mathrm{CON}$ & PKE & & \\
\hline \multicolumn{5}{|c|}{ Apparent total tract digestibility of sows } \\
\hline Dry matter $(\%)$ & 72.36 & 75.75 & 2.35 & 0.33 \\
\hline Nitrogen $(\%)$ & 61.48 & 62.79 & 3.77 & 0.81 \\
\hline Energy $(\%)$ & 68.32 & 73.97 & 2.61 & 0.15 \\
\hline \multicolumn{5}{|c|}{ Number of white blood cells of sows $\left(\times 10^{3} / \mu \mathrm{L}\right)$} \\
\hline Before farrowing & 11.82 & 9.57 & 0.83 & 0.09 \\
\hline d 3 of lactation & 11.71 & 10.09 & 2.35 & 0.63 \\
\hline d 7 of lactation & 12.70 & 11.48 & 1.43 & 0.56 \\
\hline $\begin{array}{l}\text { Frequency of diarrhea } \\
\text { of nursery pigs }(\%)^{2}\end{array}$ & 8.56 & 6.80 & - & 0.07 \\
\hline \multicolumn{5}{|c|}{ Number of white blood cells of nursery pigs $\left(\times 10^{3} / \mu \mathrm{L}\right)$} \\
\hline d 3 of lactation & 9.24 & 8.36 & 0.92 & 0.52 \\
\hline d 7 of lactation & 11.15 & 8.87 & 1.40 & 0.27 \\
\hline d 14 of lactation & 9.80 & 7.86 & 0.62 & $<0.05$ \\
\hline
\end{tabular}

$\mathrm{CON}$, control diet based on corn and soybean meal; PKE, CON+20\% palm kernel expellers; SEM, standard error of the mean.

${ }^{1}$ Values are presented as the least squares mean of 7 replicates for sows and nursery pigs (4 nursery pigs/replicate).

${ }^{2}$ Frequency of diarrhea of nursery pigs $=$ (number of diarrhea/number of nursery pig days) $\times 100$. Data was analyzed by the $x^{2}$ test.

Perez, 1993). Previous studies also showed palm kernel expellers, palm kernel meal, or diets containing those ingredients decreased crude protein or energy digestibility of growing or finishing pigs compared with soybean meal or corn-soybean meal based diets (Son et al., 2012; Sulabo et al., 2013), resulting in reduced growth performance (Kim et al., 2001; Ao et al., 2011). The data from present experiment cannot be directly compared with the data from previous studies mentioned above because the data from present experiment was for sows rather than growingfinishing pigs. However, the present experiment did not find any negative effects on nutrient digestibility as well as productive performance when sows were fed the lactation diet containing palm kernel expellers as partial replacement of corn and soybean meal. The reason for this observation may be related to a greater capacity for microbial fermentation in sows, which may contribute to better fiber digestion and energy utilization (Renteria-Flores et al., 2008), than that of grow-finishing pigs. In addition, it may be related to relatively greater fat content in PKE, which may contribute to increased retention time in the intestine (Cervantes-Pahm and Stein, 2008), compared with CON in the present experiment.

Feeding PKE to lactating sows tended $(\mathrm{p}<0.10)$ to increase average body weight gain of piglets compared with CON (Table 2). As mentioned above, milk production of lactating sows is also very important because it can directly affect litter performance. In addition, previous studies showed an increased fat content in sow diets increased milk fat contents (Pettigrew, 1981; Lauridsen and Danielsen, 2004), resulting in improvement of piglet performance (Lauridsen and Danielsen, 2004). Similarly, the present experiment showed increased average weight gain of piglets from sows fed PKE compared with CON. The reason for this observation may be associated with relatively greater fat content in PKE compared with CON, which may have contributed to greater fat contents in milk.

No difference was found on preweaning mortality of piglets from sows fed either PKE or CON during lactation (Table 2). However, frequency of diarrhea of piglets tended $(\mathrm{p}<0.10)$ to be reduced by feeding PKE to lactating sows compared with CON (Table 3). Moreover, the PKE decreased WBC of sows before farrowing $(\mathrm{p}<0.10)$ and their piglets on $\mathrm{d} 14$ of lactation $(\mathrm{p}<0.05)$ compared with CON. Generally, the WBC counts are one of the typical indicators of inflammation (Gordon-Smith, 2009) that can affect appetite or feed intake and nutrient competition between immune system and growth (Doeschl-Wilson et al., 2009). In addition, previous studies showed that palm kernel expellers contained relatively greater $\beta$-mannans compared with other oil-seed co-products and conventional ingredients (Sulabo et al., 2013) and that mannanoligosaccharides in swine diets influenced immune system and growth and productive performances positively (Miguel et al., 2004; Pettigrew et al., 2005; Che et al., 2011). The reason for the reduced $\mathrm{WBC}$ by feeding PKE is possibly related to relatively greater $\beta$-mannans in PKE compared with $\mathrm{CON}$, which may contribute to reduced inflammation of sows before and after farrowing (Otten et al., 2013). Furthermore, energy from this reduced inflammation may contribute to milk (colostrum and/or milk) production and then to health and performance of piglets.

To our knowledge, the present experiment is the first to show the effects of palm kernel expellers in lactating sow diets and thus there are little corresponding data to compare with our findings. Therefore, more research is needed to determine effects of palm kernel expellers in sow diets and to verify its assumed mechanisms in productive performance and health standpoints that were not determined in the present experiment.

\section{CONCLUSION}

In conclusion, addition of $20 \%$ palm kernel expellers to lactation diet based on corn and soybean meal had no negative effects on productive performance, nutrient digestibility, and WBC changes of lactating sows.

\section{ACKNOWLEDGMENTS}

This research was supported by a grant from the Next- 
Generation BioGreen 21 Program (No. PJ00811604), Rural Development Administration, Republic of Korea.

\section{REFERENCES}

Adeola, O. 2001. Digestion and balance techniques in pigs. In: Swine Nutrition (Eds. A. J. Lewis and L. L. Southern). CRC press LLC, Boca Raton, FL, USA. pp. 903-916.

Ao, X., T. X. Zhou, Q. W. Meng, J. H. Lee, H. D. Jang, J. H. Cho, and I. H. Kim. 2011. Effects of a carbohydrates cocktail supplementation on the growth performance, nutrient digestibility, blood profiles, and meat quality in finishing pigs fed palm kernel meal. Livest. Sci. 137:238-243.

AOAC International. 2005. Official Methods of Analysis, 18th edn. Association of Official Analytical Chemists, Arlington, VA, USA.

Cervantes-Pahm, S. K. and H. H. Stein. 2008. Effect of dietary soybean oil and soybean protein concentration on the concentration of digestible amino acids in soybean products fed to growing pigs. J. Anim. Sci. 86:1841-1849.

Che, T. M., R. W. Johnson, K. W. Kelley, W. G. Van Alstine, K. A. Dawson, C. A. Moran, and J. E. Pettigrew. 2011. Mannan oligosaccharide improves immune responses and growth efficiency of nursery pigs experimentally infected with porcine reproductive and respiratory syndrome virus. J. Anim. Sci. 89:2592-2602.

Doeschl-Wilson, A. B., I. Kyriazakris, A. Vincent, M. F. Rothschild, E. Thacker, and L. Galina-Pantoja. 2009. Clinical and pathological responses of pigs from two genetically diverse commercial lines to porcine reproductive and respiratory syndrome virus infection. J. Anim. Sci. 87:16381647.

Eissen, J. J., E. Kanis, and B. Kemp. 2000. Sow factors affecting voluntary feed intake during lactation. Livest. Prod. Sci. 64:147-165.

Goering, H. K. and P. J. van Soest. 1970. Forage fiber analysis (apparatus, reagents, procedures and some applications). Agriculture Handbook No. 379. ARS, USDA, Washington, DC, USA.

Gordon-Smith, T. 2009. Structure and function of red and white blood cells. Medicine 37:119-124.

Hoffman, L. A. and A. Baker. 2011. Estimating the substitution of distillers' grains for corn and soybean meal in the U.S. feed complex. A report from the Economic Research Service, U.S. Department of Agriculture http://www.ers.usda.gov/Publications /FDS/2011/09Sep/FDS11I01/FDS11I01.pdf Accessed July 17, 2013.

Kim, B. G., J. H. Lee, H. J. Jung, Y. K. Han, K. M. Park, and I. K. Han. 2001. Effect of Partial replacement of soybean meal with palm kernel meal and copra meal on growth performance, nutrient digestibility and carcass characteristics of finishing pigs. Asian Australs. J. Anim. Sci. 14:821-830.

Koketsu, Y., G. D. Dial, J. E. Pettigrew, W. E. March, and V. L. King. 1996. Characterization of feed intake patterns during lactation in commercial swine herds. J. Anim. Sci. 74:12021210.

Lauridsen, C. and V. Danielsen. 2004. Lactational dietary fat levels and sources influence milk composition and performance of sows and their progeny. Livest. Prod. Sci. 91:95-105.
Miguel, J. C., S. L. Rodriguez-Zas, and J. E. Pettigrew. 2004. Efficacy of Bio-Mos for improving nursery pig performance. J. Swine Health Prod. 12:296-307.

National Research Council. 2012. Nutrient Requirements of Swine, 11th Ed. National Academy Press, Washington, DC, USA.

Noblet, J. and J. M. Perez. 1993. Prediction of digestibility of nutrients and energy values of pig diets from chemical analysis. J. Anim. Sci. 71:3389-3398.

Otten, W., E. Kantiz, M. Tuchscherer, M. Grabner, G. Nurnberg, O. Bellmann, U. Hennig, C. Rehfeldt, and C. C. Metges. 2013. Effects of low and high protein:carbohydrate ratios in the diet of pregnant gilts on maternal cortisol concentrations and the adrenocortical and sympathoadrenal reactivity in their offspring. J. Anim. Sci. 91:2680-2692.

Pettigrew, J. E. 1981. Supplemental dietary fat for peripartal sows: A review. J. Anim. Sci. 53:107-117.

Pettigrew, J. E., J. C. Miguel, and S. Carter. 2005. Bio-Mos® in sow diets: performance responses and economics. In: Nutritional Biotechnology in the Feed and Food Industries, Proceedings of Alltech's $21^{\text {st }}$ Annual Symposium (Eds. T. P. Lyons and K. A. Jacques). Nottingham University Press, Nottingham, UK. pp. 213-220.

Ravindran, V. and R. Blair. 1992. Feed resources for poultry production in Asia and the Pacific. II. Plant protein sources. World Poult. Sci. J. 48:205-231.

Renteria-Flores, J. A., L. J. Johnston, G. C. Shurson, and D. D. Gallaher. 2008. Effect of soluble and insoluble fiber on energy digestibility, nitrogen retention, and fiber digestibility of diets fed to gestating sows. J. Anim. Sci. 86:2568-2575.

Singhania, R. R., C. R. Soccol, and A. Pandey. 2008. Application of tropical agro-industrial residues as substrate for solid-state fermentation processes. In: Current Developments in Solidstate Fermentation (Eds. A. Pandey, C. R. Soccol, and C. Larroche). Springer, New York, USA. pp. 412-442.

Son, A. R., S. Y. Ji, and B. G. Kim. 2012. Digestible and metabolizable energy concentrations in copra meal, palm kernel meal, and cassava root fed to growing pigs. J. Anim. Sci. 90:140-142.

Son, A. R., S. Y. Shin, and B. G. Kim. 2013. Standardized total tract digestibility of phosphorus in copra expellers, palm kernel expellers, and cassava root fed to growing pigs. Asian Australas. J. Anim. Sci. 26:1609-1613.

Son, A. R., Y. Hyun, J. K. Htoo, and B. G. Kim. 2014. Amino acid digestibility in copra expellers and palm kernel expellers by growing pigs. Anim. Feed Sci. Technol. 187:91-97.

Song, M., S. K. Baidoo, G. C. Shurson, M. H. Whitney, L. J. Johnston, and D. D. Gallaher. 2010. Dietary effects of distillers dried grains with solubles on performance and milk composition of lactating sows. J. Anim. Sci. 88:3313-3319.

Sulabo, R. C., W. S. Ju, and H. H. Stein. 2013. Amino acid digestibility and concentration of digestible and metabolizable energy in copra meal, palm kernel expellers, and palm kernel meal fed to growing pigs. J. Anim. Sci. 91:1391-1399.

Wachenheim, C. J., P. Novak, E. A. DeVuyst, and D. K. Lambert. 2006. Demand estimation for agricultural processing coproducts. Great Plains Res. 16:85-94.

Williams, C. H., D. J. David, and O. Iismaa. 1962. The determination of chromic oxide in faeces samples by atomic absorption spectrophotometry. J. Agric. Sci. 59:381-385. 